\title{
Making initiatives resonate: how can non-state initiatives advance national contributions under the UNFCCC?
}

\author{
Lukas Hermwille ${ }^{1,2}$ (D)
}

Accepted: 3 April 2018 / Published online: 9 April 2018

(C) The Author(s) 2018

\begin{abstract}
The international governance landscape on climate change mitigation is increasingly complex across multiple governance levels. Climate change mitigation initiatives by non-state stakeholders can play an important role in governing global climate change. The article addresses the relationship between intergovernmental and transnational governance processes in global climate governance. Particularly, the article aims to complement existing research on the role of "orchestration" by and through the UNFCCC process by focusing on how successful transnational initiatives can resonate within the intergovernmental negotiation process in order to inspire more ambitious climate action also on the part of national governments. This issue is addressed by systematically analysing interdependencies between transnational and international governance. Building on a structurational regime model, the article develops a theory of change of how and through which structuration channels non-state initiatives can contribute to changing the politics of international climate policy, traces existing UNFCCC processes and the Paris Agreement with a view to identifying inroads for a more direct feedback from non-state initiatives and derives recommendations on how and under which agenda items positive experiences can resonate within the UNFCCC negotiation process.
\end{abstract}

Keywords UNFCCC $\cdot$ Paris Agreement $\cdot$ Regime complex · Orchestration · Transnational climate governance $\cdot$ Non-state and subnational actors

Lukas Hermwille

lukas.hermwille@wupperinst.org

1 Wuppertal Institute for Climate, Environment and Energy, Döppersberg 19, 42103 Wuppertal, Germany

2 Institute for Environmental Studies (IVM), Vrije Universiteit Amsterdam, De Boelelaan 1085, 1081 HV Amsterdam, The Netherlands 


\section{Introduction}

The global governance landscape has shifted significantly in recent years. More traditional intergovernmental organisations such as the World Trade Organisation (WTO), World Bank and the United Nations' Framework Convention on Climate Change (UNFCCC) are complemented by an increasingly complex patchwork of transnational governance initiatives (e.g. Abbott 2012; Bulkeley et al. 2014; IPCC 2014; Jordan et al. 2015; Newell et al. 2012). This is particularly true for climate change governance in which an increasingly complex governance landscape has emerged (Pattberg and Widerberg 2017) in part as a response to a lack of a comprehensive multilateral agreement after the "diplomatic disaster" (Grubb 2010, p. 127) of the Copenhagen climate conference (see Bäckstrand et al. 2017).

The successful adoption of the Paris Agreement at the $21^{\text {st }}$ Conference of the Parties of the UNFCCC marks another point of inflection for global climate governance. The Paris Agreement explicitly acknowledges the existence and value of the wider international climate regime complex, but it may also redefine the configuration and interdependencies within it. With its 5-yearly cycle of NDCs (Art. 4), international review under the Agreements transparency mechanism (Art. 13) and global stocktakes of collective progress (Art. 14) the Paris Agreement deploys a "pacemaker" (Hermwille 2016a) that stimulates and synchronises climate policy making on the national, transnational and international levels (UNFCCC 2016a). It creates periodic political moments, each of which can move the world closer to an incrementally more sustainable and ultimately carbon-free future. However, actors from all political levels are needed to breathe life into these political moments.

Transnational climate initiatives and non-state actors can play a role in fostering the required momentum. In fact, non-state and subnational actors are becoming more and more salient also on the global level. The UNFCCC Secretariat's NAZCA (Non-State Actor Zone for Climate Action) platform currently (January 2018) features commitments to climate action from more than 12,500 companies, cities, subnational, regions, investors, and civil society organisations (UNFCCC 2018). While the effectiveness of such initiatives is extremely difficult to assess (Bulkeley et al. 2014; Widerberg and Stripple 2016) and first assessments provide very mixed evidence on the potential for transnational climate initiatives to contribute to closing the "mitigation gap" left by a lack of mitigation ambition on the part of national commitments (Graichen et al. 2016; Michaelowa and Michaelowa 2017; Roelfsema et al. 2018). Even if transnational governance initiatives are successful and help implementing effective climate change mitigation, there may be a risk that transnational governance may crowd out ambition at the national level. On the other hand, Cao and Ward argue that "transnational ties do more than link the organisations directly involved. They are conduits through which information can flow between countries, linking organisations not directly involved in TCG [(transnational climate governance)]. As such, they present the possibility of diffusion of policy and learning (Cao and Ward 2017, p. 97). In that sense transnational governance initiatives may have effects beyond the realisation of direct emission reductions.

This article theorises and empirically assesses the influence that (effective) transnational governance processes may have on the intergovernmental negotiations under the UNFCCC and the Paris Agreement (see Betsill 2015). While much has been said about "orchestration" (Abbott 2012; Abbott et al. 2015; Chan and Pauw 2014; Hale and Roger 2014), these works typically focus on the more visible task of a conductor: giving directions. This paper 
instead focuses on the essential capacity of an orchestrator to listen and perceive what is happening among those who are being orchestrated.

The article will apply a structurational regime model (Sect. 2) to theorise the relationship between transnational governance processes and the intergovernmental negotiations under the UNFCCC and the Paris Agreement. The structurational regime model (on the basis of Arts 2000; Hermwille et al. 2017) suggests that adequate feedback from successful transnational climate action into the intergovernmental negotiations could facilitate increased ambition also on the part of nation states in current and subsequent NDC cycles. Yet, as our empirical discussion of non-state and subnational actors within the UNFCCC process (Sect. 3) demonstrates, mechanisms of continuous feedback through monitoring and reporting, and in particular periodical reflection and re-evaluation of the set goals as well as the practices of implementation with respect to transnational governance initiatives is still largely missing at the intergovernmental level. The current institutional set-up of the UNFCCC resembles a structurational one-way street: the UNFCCC orchestrates transnational governance initiatives to some extent but there are hardly any mechanisms to feed back immediately into the intergovernmental process. Section 4 discusses how this deficit could be remedied and suggest potential inroads in the ongoing negotiations to create such structurational short-cuts so as to maximise "catalytic linkages" (Betsill 2015) between the transnational and intergovernmental realms. Section 5 concludes.

\section{Theorising complex climate governance}

\subsection{The increasingly complex climate governance landscape and the role of non-state actors}

The global climate governance landscape has seen substantial changes in recent years. While up until the late 1990s, scholars of international environmental governance tried to develop recommendations or design principles for institutional design of integrated issuespecific multilateral regimes (McGinnis and Ostrom 1996; e.g. Wettestad 1999; Young 1997) it soon became clear that such hoping for silver bullet international agreements may have been somewhat naive. As Young notes: "it is unlikely that we will be able to formulate a set of simple generalisations that spell out necessary conditions for success in efforts to create international regimes or to operate them effectively" (Young 1997, p. 214). In fact, the global governance landscape is to some extent emergent (c.f. De Búrca et al. 2014, pp. 3-4). Research interest has therefore shifted towards describing a trend of increasing "fragmentation" (e.g. Biermann et al. 2009; Pattberg et al. 2014; Zelli 2011) or increasing "polycentricity" (Jordan et al. 2015; Oberthür 2016; Ostrom 2014) of the global governance architecture and an analysis of the consequences thereof including investigating the institutional interplay between various elements of the regime complex (e.g. Oberthür and Gehring 2006).

It has been argued that the benefits of the more divers regime complex can be increased if the various governance initiatives are to some extent "orchestrated" (Abbott 2012; Abbott et al. 2015; Chan and Pauw 2014; Hale and Roger 2014). "Orchestration", in the terms of Abbott et al. (2015), specifies a soft and indirect mode of governance as opposed to more hierarchical hard and direct modes. It builds on coexistence and complementarity rather than competing forms of governance. Moreover, the increasing plurality in the climate governance landscape allows to experiment with innovative policies and governance 
approaches (Hoffmann 2011; Jordan and Huitema 2014). Some authors therefore go one step further by proposing "experimentalist governance" as a "a recursive process of provisional goal setting and revision based on learning from comparison of alternative approaches to advancing these goals in different contexts" (Overdevest and Zeitlin 2014, p. 25; see also De Búrca et al. 2014; Sabel and Zeitlin 2008, 2012).

The Paris Agreement now adds a regime layer of central intergovernmental governance to the emerging transnational regime complex. This challenges us to think about the relationships and interdependencies between the two. The Paris Agreement, with its long-term goals, the open-ended framework and its transparency mechanism can fulfil some of the "key deliberation-fostering steps" entailed by an ideal typical experimentalist regime (De Búrca et al. 2014, p. 478), not only for nation states but, as a common reference point, also for other forms of governance. It can help develop a broadly shared perception of the problem at hand, and it establishes the accord of a dynamic and open-ended framework, and sets goals at the aggregate level. It also stipulates the implementation of these goals at subordinate (national) level taking into account context-specific circumstances and explicitly welcomes the contributions of non-state and subnational actors.

While the different contributions reviewed above by and large focussed on the structure of the international governance landscape-be it in descriptive or in normative termsanother stream of literature has focussed on the role of agency of non-state actors within the international regime, particularly within the UNFCCC negotiations. Building on the pioneering work of Newell (2000), there has been considerable academic interest in the role of non-state actors, in particular environmental NGOs, business representatives and academics, within the UNFCCC negotiations. The majority of these works conceptualised non-state actors as lobbyists or "NGO diplomats" (Betsill and Corell 2008, p. 3). Schroeder and Lovell (2012), for example, have studied how observers can and do influence the ongoing negotiations through official side-events that complement the formal negotiations at each Conference of the Parties (COP) of the UNFCCC. These works concur in that they recognise the influence of non-state actors on the negotiations, in particular through influencing the agenda of ongoing negotiations (Betsill and Corell 2008; Nasiritousi et al. 2016). Moreover, they find that COPs have become "mega events where global agendas are set, thinking is joined-up and leadership emerges" (Schroeder and Lovell 2012, p. 26; see also Aykut et al. 2017).

The insights generated by this stream of literature do provide a compelling perspective. Yet this perspective is only a partial one. It portrays non-state actors as political actors that aim to influence national governments. This, however, is not necessarily a primary intention of many non-state and subnational actors that have become governors in their own right (see Kuyper et al. 2018). There is a need to look into "catalytic linkages" between the intergovernmental and transnational realms that go beyond non-state actor participation in side-events and lobbyism in the negotiation hallways (Betsill 2015).

\subsection{A structurational regime model of the UNFCCC: justification}

In order to describe the impact of transnational climate initiatives on the intergovernmental process, a theory of decision making is required that allows both to conceptualise agency with non-state and subnational actors as well as nation states. Notably, most literature studying regime complexes still relies on state-centric ontologies (see Jordan et al. 2015; Schroeder and Lovell 2012). Moreover, for the purpose of this paper, a temporal perspective is required since the Paris Agreement is a dynamic and open-ended 
legal framework and the impact that transnational governance initiatives can have on future NDC cycles is of particular interest. Last but not least, the model needs to balance structure and agency in a nuanced way. A deterministic structure-based ontology would exclude the possibility of successful bottom-up governance initiatives while a strictly agency-focussed approach would most likely underrate the influence of international law and environmental multilateralism in legitimising and structuring climate action.

For the purposes of this article, a structurational regime model (Arts 2000) appears to be particularly suitable as it meets the above mentioned requirements (see Okereke et al. 2009; Wendt 1987). Structuration theory provides an ontological foundation that can accommodate all three requirements: explicit modelling of non-state/subnational actors as "governors" (Okereke et al. 2009, p. 61), temporal dynamics, and balancing structure and agency. Structuration theory has been developed precisely to bridge the structureagency divide. It argues for a duality of agency and structure, "agents and structures are not kept apart but [...] are mutually constitutive of each other" (Stones 2005, p. 21). Individual behaviour is co-determined by the structures in which all agents operate and in turn actions change or reproduce structures. Giddens specifies three modes of structuration (Giddens 1984): domination as authoritative or allocative power/control over resources and legitimation (norms) and signification (collective meaning) as the rules or, as Sewell (2005) calls it, cognitive "schemas". In acting, agents reproduce and thereby reinforce these structures of domination, legitimation and signification and hence close the cycle of structuration. Structuration theory provides a nuanced conceptualisation of structure and agency and the iterative, morphogenetic structuration cycle is inherently temporal (Sewell 2005).

A structurational approach may also help to accommodate the role(s) of various relevant actors in international climate policy beyond the nation state (Okereke et al. 2009). Arts (2000) developed a structurational regime model precisely for this purpose and Hermwille et al. (2017) have modified and applied it to analyse the recent development of the UNFCCC negotiation process. This structurational regime model will also inform the subsequent analysis in this article.

In a nutshell, the structurational regime model argues that politics (in this case international climate policy) is a means to change (unsustainable) structures deliberately and through a formalised process. As Hermwille et al. (2017) argue, the UNFCCC and the associated policy processes mostly fail to provide structure by the mode of domination (mainly due to the anarchic character of the concert of sovereign states), but do provide signification and legitimation. "The UNFCCC structures agency at various levels and through various channels. It structures agency at the level of nation states and through the nation states, through the implementation of treaties and subsequently implementing decisions in the respective national laws of the parties to the treaty. But the UNFCCC also structures the behaviour of the other constituents of socio-economic systems directly by providing shared signification and legitimation to transnational and subnational institutions as well as to corporations, consumers and citizens" (Hermwille et al. 2017, p. 3).

It is important to note that the signification and legitimation provided by the UNFCCC are not unique. They intersect with a multiplicity of other structures, sometimes in a competing and sometimes in a complementary way (see Sewell 2005). Also, the policy process is itself subject to structure and follows certain formal and informal rules. "The key actors in the negotiations, government officials, diplomats and ministers, but also participants from civil society, business organisations, international organisations, and academia, 
Fig. 1 Schematic illustration of the channels and interdependencies of the structuration cycle in the context of the UNFCCC. Arrows indicate structuration channels

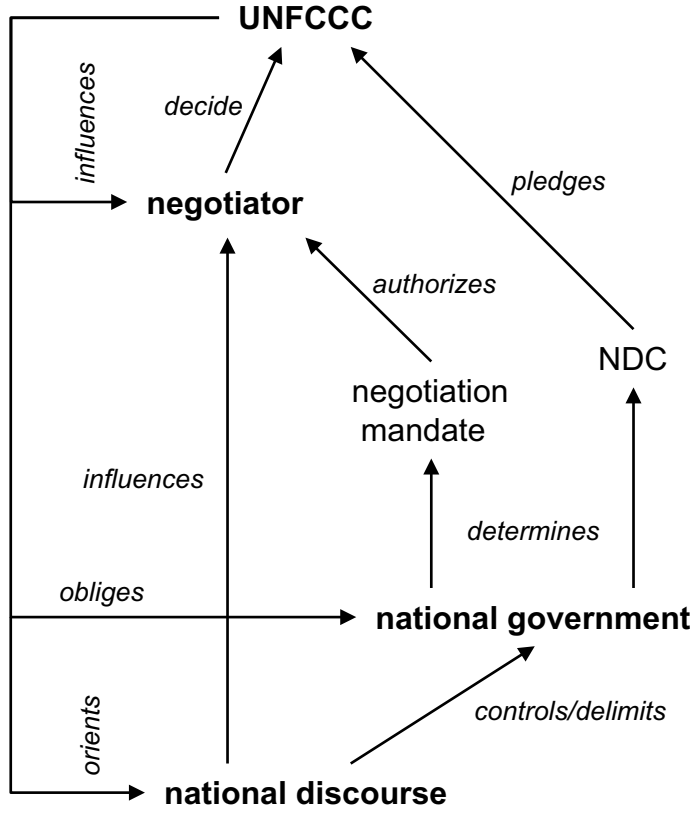

all draw on rules and resources embedded in their respective structures" (Hermwille et al. 2017, p. 4).

\subsection{The structurational regime model in application}

Having introduced the ontological foundations of the analysis, we can now turn to the specific case and derive a simple structuration model of global climate regime complex which includes transnational climate initiatives as a locus of agency. As outlined above, structuration occurs through repeated interaction, of agents taking decisions enabled and/or constrained by existing structures and thereby reinforcing structures both for themselves as well as for others (Stones 2005). Developing an applied model therefore needs to focus on the various channels of interaction or "structuration channels" among and between actors. Figure 1 below illustrates relevant channels of structuration and interdependencies within the UNFCCC.

Decisions at the UNFCCC are ultimately taken by individuals-delegates of governments of the member states. These negotiators are typically authorised by a negotiation mandate provided by their respective national government. Negotiation mandates vary in how widely or narrowly defined they are, but even in relatively narrowly defined mandates, i.e. mandates that feature numerous explicitly defined "red lines", negotiators typically have some freedom to bargain and approve of compromises if necessary. Within their remaining room to manoeuvre, it is reasonable to assume that negotiators will take into account both dynamics and the rules of the game (North 1990) of the acute negotiations under the UNFCCC as well as structures emanating from their respective national discourses (Milkoreit 2017).

Alongside negotiators, national governments therefore remain a decisive factor and locus of agency in the proposed model. Under the Paris Agreement, Parties are obliged to 


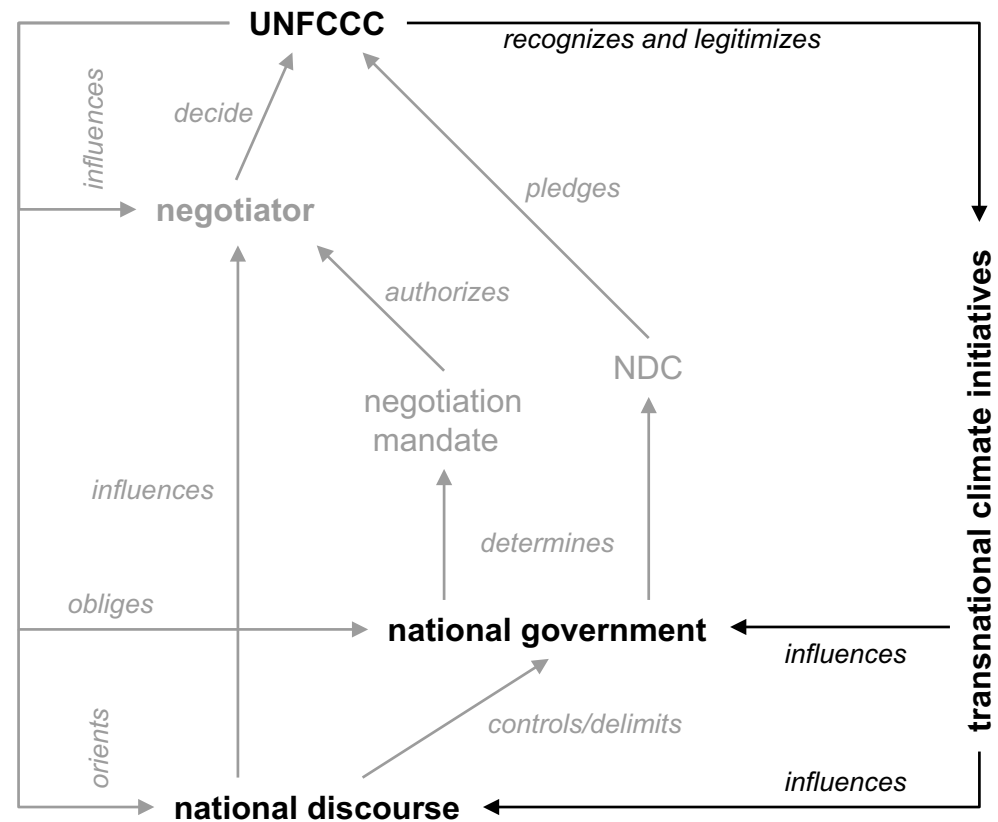

Fig. 2 Structuration channels and interdependencies of transnational climate initiatives and the intergovernmental negotiations under the UNFCCC. Arrows indicate structuration channels

"prepare, communicate and maintain successive nationally determined contributions [... and to] pursue domestic mitigation measures, with the aim of achieving the objectives of such contributions" (UNFCCC 2016a, Art. 4.2). As the name indicates, these so-called nationally determined contributions (NDCs) are determined in sovereign capitals and not under international law and the immediate negotiation pressure of a UNFCCC Conference of the Parties. The article therefore conceptualises them as a separate channel of structuration (see Fig. 1).

Both negotiators and the national government are influenced to some extent by their respective national discourse. The national discourse and dominant narratives therein delimit the scope of the "politically feasible". Ultimately, politicians need to provide meaningful explanations for their decisions and these explanations need to resonate in the political discourse of their countries. If not, legitimation will erode and at least in a democratic system, political power will hardly endure without legitimation (see Miskimmon et al. 2013).

National discourses are also not independent from structuration. The UNFCCC and the associated processes also deliver norms and collective meaning that provide a certain discursive structure including for wider political discourses. A key example here would be the $2{ }^{\circ} \mathrm{C}$ limit which has been strongly engrained by the UNFCCC as a widely shared norm (Hermwille et al. 2017; Morseletto et al. 2016).

Building on this understanding of the general structuration processes within and beyond the UNFCCC, we can now turn to the role of transnational climate initiatives in the intergovernmental negotiation process. Transnational climate initiatives interact with three elements of the regime model: they allow for structuration by influencing national governments directly or via shaping national discourses and they are increasingly recognised 
directly at the UNFCCC level (see discussion below). These connections are indicated by the arrows depicted in Fig. 2 below.

Successful climate initiatives can influence national discourses in at least two ways. Firstly, they can ease some of the distributive burden implied in some mitigation instruments such as, for example, emissions trading: if transnational climate initiatives are successful in abating greenhouse gas emission, this can reduce the required mitigation effort in other parts of the economy of a given country, making more ambitious overall mitigation goals more attainable politically and economically.

Secondly, transnational climate initiatives can contribute not only by mitigating greenhouse gas emissions but also as originators or contributors of transformational change. The scope and diversity of transnational climate initiatives is tremendous (e.g. Bulkeley et al. 2014; Jordan et al. 2015; Widerberg and Pattberg 2015), but at least some initiatives may create socio-technical niches, protected spaces, that allow to experiment with and further develop new and sustainable ideas, artefacts and practices (Smith 2007; Smith and Raven 2012). Growing evidence from the field of transition research suggests that innovations developed in niches are the essential "seeds of transition" (Geels and Schot 2010, p. 24), but without an appropriate socio-political environment they cannot sprout (Geels and Schot 2010). In demonstrating the feasibility and economic viability of mitigation activities, transnational initiatives can help to establish new narratives in the national political discourse and thus allow to reshape the room of the politically feasible (Hermwille 2016b; Miskimmon et al. 2013).

Influence on national governments is considered to be much more intermediate, but can occur when successful initiatives create and reinforce epistemic communities (Haas 1992) or powerful instrumental constituencies (Voß and Simons 2014) that include government officials, consultants and bureaucrats.

With respect to the structuration channels between the transnational level and the intergovernmental negotiation process under the UNFCCC, the account of the role of non-state and subnational actors in the UNFCCC negotiations indicates that structuration flows only in one direction (hence the arrow in Fig. 2). The UNFCCC clearly recognises the many complementary governance initiatives and consequently to some extent the de facto emergence of an increasingly polycentric climate governance system. The decisions accompanying the Paris Agreement explicitly welcome the efforts of non-Party stakeholders (UNFCCC 2016b, paras. 117, 133). Parties decided even to launch a work programme on capacity building with the aim of "[f]ostering global, regional, national and subnational cooperation" (UNFCCC 2016b, para. 73d). It is also quite clear that normative goals set out by UNFCCC such as the $2{ }^{\circ} \mathrm{C}$ limit, the call for achieving a balance between anthropogenic greenhouse gas emissions and removals by sinks in the second half of the century (UNFCCC 2016a, Art. 4), and the goal to make "finance flows consistent with a pathway towards low greenhouse gas emissions and climate-resilient development" (UNFCCC 2016a, Art 2.1c) legitimise the efforts of non-Party actors (see Hermwille et al. 2017).

The structurational regime model suggests that immediate feedback from the transnational level could help improve overall climate governance, ensuring that advances made on the transnational level-either in terms of accelerated implementation or successful experiments with policy innovation-are duly taken into account and do not crowd out ambition on the part of the nation states (see Meadows 1999). Yet, as the empirical analysis of the subsequent section will demonstrate, advances made by transnational climate initiatives echo primarily on the national level and therefore at best reproduce and reinforce structures only indirectly with regard to the UNFCCC. There are very limited inroads for 
transnational climate initiatives to immediately feed back into the intergovernmental negotiation process.

\section{Empirical relations between the transnational, international and national realms of climate governance}

\subsection{Transnational climate initiatives within the UNFCCC}

The subsequent section provides a brief account of formal and informal interactions among non-state and subnational actors on the one hand and the intergovernmental negotiation process on the other hand. It is based on the author's regular participation in UNFCCC conferences at the annual COPs and intersessional meetings, review of the coverage of UNFCCC negotiations by the Earth Negotiation Bulletin (IISD Reporting Services 2018) as well as "crowdsourced" minutes from relevant negotiation sessions circulated by various members of the Climate Action Network (CAN). In order to further substantiate the above mentioned information and to triangulate initial findings, four additional expert interviews were held with a member of the French delegation for COP21 (expert A), a senior legal advisor to the Alliance of Small Island States (AOSIS) negotiation group (expert B), and two staff members of the UNFCCC Secretariat (experts C \& D). All interviewees were closely involved in the respective processes described below. ${ }^{1}$

Until fairly recently, the recognition and engagement of trans- and subnational climate initiatives was hardly institutionalised under the UNFCCC. Given the intergovernmental nature of the UNFCCC, the status of non-state actors is originally limited to an observer role. In the past, there had not been many avenues for successful transnational climate initiatives to communicate their achievements into the UNFCCC process, apart from presentations at side-events. One way of formal recognition would have been via the national communications of the parties. The template for national communications foresees a chapter on subnational activities, but arguably, it would be rather difficult to adequately present border-crossing transnational initiatives as subnational activities. What is more, national communications are typically filed and stored after the review process but have little resonance within the intergovernmental negotiations.

However, in recent years, there was growing attention and appreciation of transnational climate initiatives in one particular negotiation stream under the UNFCCC. The Ad hoc Working Group on the Durban Platform (ADP) that carried out the negotiations in the runup to the COP21 in Paris was organised along two negotiation tracks: Workstream 1 was tasked to negotiate what became the Paris Agreement and Workstream 2 started out as a process to negotiate new and increased mitigation commitments for industrialised (Annex 1) countries for the time before 2020. Workstream 2 was not successful in that regard, but at least in part as a response to the lack of progress the focus of the workstream changed considerably and added some novel aspects to the UNFCCC negotiations: it created a room to explore the contributions of international and transnational climate initiatives in closing the "mitigation gap" between the pledges of industrialised countries and the atmospheric

\footnotetext{
1 The interviews were held on 2 February 2017 (expert A), 8 February 2017 (expert B), and 22 February 2017 (experts C \& D) respectively. They were conducted by telephone in semi-structured fashion. Audio recordings are available from the author upon request.
} 
needs to limit global warming to $1.5 / 2{ }^{\circ} \mathrm{C}$ above pre-industrial levels (Ott et al. 2014; Widerberg and Pattberg 2015).

The Alliance of Small Island States (AOSIS) had proposed to convene a series of technical expert meetings (TEMs), in order to create a space for non-political and facilitative discussions (expert B). The first of these meetings was successfully held at COP19 in Warsaw 2013 as an in-session workshop on urbanisation and the role of subnational governments in facilitating climate action in cities (Sterk et al. 2013). Building on this positive experience, parties agreed to continue this format also during the intersessional meetings in 2014 and at COP20 in Lima. While the first TEMs were rather generic in nature, in Lima, Parties decided to advance from the exchange of information to a more action-oriented approach. Specifically, they agreed to build on the results of earlier TEMs, to go into more detail and to "focus on actionable policy options" (UNFCCC 2015, para. 19).

The mandate of the ADP which had housed the TEMs in the last 2 years terminated with the adoption of the Paris Agreement. The question in Paris, therefore, was, whether this process would continue, with what kind of mandate and where it should be housed under the UNFCCC architecture. Parties agreed to continue the series of TEMs, now dubbed "technical examination process" (TEP), under the joint auspices of SBI and SBSTA and to strengthen it by inter alia requesting the Technology Executive Committee (TEC) and the Climate Technology Centre and Network (CTCN) to engage in the process and enhance their facilitative efforts. Also parties encouraged the Green Climate Fund (GCF) to engage in the process and to provide information with respect to its contribution to the implementation of policies and measures identified in the TEP. Paris provided also an extensive mandate for the Secretariat to organise the process and disseminate its results (UNFCCC 2016b, paras. 109-113).

Many negotiators including early proponents of the format were, however, not very satisfied with the current form of the TEP, in particular because a constructive discussion between delegates-being usually senior staff of ministries of the environment or foreign affairs-and highly specialised issue experts were difficult to maintain (experts A and B). In the words of one of the experts interviewed: "There was this global understanding that the process should help to increase ambition through scaling up and replicating best practices. The first part went very well in terms of identifying best practices [...] but the second part-how the governments take these issues forward-was the weakness of the process so far" (expert C).

At COP23, this was also reflected in the decision text relating to the mandated review of the TEP for mitigation and adaptation, respectively. In particular, parties agreed to "strongly urge [...] to focus the technical examination processes on specific policy options and opportunities for enhancing mitigation and adaptation that are actionable in the short term, including those with sustainable development co-benefits" (UNFCCC 2017, para. 2).

The general value of such technical processes for intergovernmental negotiations, though, is exemplified by the Technological and Economic Assessment Panel (TEAP) under Article 6 of the Montreal Protocol on Substances that Deplete the Ozone Layer (United Nations 1989). In fact, the TEMs were proposed specifically with the success story of the TEAP in mind (expert B). The TEAP and its dependent issue-specific Technical Options Committees (TOCs) were paramount to driving ambition in the context of the Montreal Protocol (see Andersen 2015, p. 146). According to Andersen (2015), the international cooperation of technical experts under the umbrella of the TEAP and its subcommittees helped to inter alia resolve technical myths and misconceptions as well as to advance the development of new solutions by emancipating experts to integrate new insights also in their respective institutions and development of new technology. These advancements 
paved the way for a gradual increase of the ambition and ultimately the success of the Montreal Protocol (Andersen and Sarma 2002; Gonzalez et al. 2015). Consequently, de Bùrca et al. highlighted the TEAP and the TOCs as "they came to institutionalise the broad stakeholder participation, corrigibility of goals and continuous learning from performance monitoring that defines an experimentalist organization" (De Búrca et al. 2014, p. 482).

The incorporation of non-state and subnational actors, however, was not limited to the technical level. The first high-level political event featuring transnational climate initiatives was held at the occasion of COP20 in Lima to showcase good practices and provide a spotlight for policy makers to announce new initiatives and/or to increase the ambition of existing ones. Hosted by then COP-President Manuel Pulgar-Vidal, the event included contributions from a wide range of stakeholders exceptional for a formal UNFCCC high-level event. Alongside the Secretary General of the United Nations also civil society representatives, subnational governments and business representatives had the opportunity to speak (Ott et al. 2014). Manuel Pulgar-Vidal also launched the Non-state Actor Zone for Climate Action (NAZCA) (UNFCCC 2018), a web-based database maintained by the UNFCCC Secretariat in which all sorts of non-state and subnational actors can register their commitments (see above).

The Lima-Paris Action Agenda (LPAA) was continued in Paris. The French COP Presidency even considered the LPAA as the "fourth pillar of the Paris Agreement" (Ségolène Royal cited in Republique Française 2015). Meetings were held nearly every day on a divers set of issues. And the idea of putting climate initiatives on the spotlight worked well. Several high-profile initiatives were announced in the context of the LPAA. Most noteworthy perhaps are the Africa Renewable Energy Initiative (AREI) of 54 African States that aims to install $300 \mathrm{GW}$ of new renewable energy generation capacity by 2030 , and "Mission Innovation", an initiative to expedite research and development on low-carbon technologies, which is backed by an initiative of 28 billionaire investors headed by Bill Gates (Obergassel et al. 2015, 2016).

Building on these successes, parties have agreed to continue and expand the series of events under the auspices of so-called "high-level champions" through to 2020 (UNFCCC 2016b, paras. 120-123). The first two champions-Laurence Tubiana, who had secured the Paris success as lead of the French COP Presidency team, and Hakima El Haite, Minister Delegate in Charge of Environment of the Minister of Energy, Mining, Water and Environment of Morocco-further strengthened the engagement of non-state and subnational actors inter alia by further developing the structure of the TEPs by e.g. setting up a dedicated website which summarises the results of TEPs in an accessible way (UNFCCC 2016c). Their work culminated in the "Marrakech Partnership for Global Climate Action" or "Global Climate Action Agenda" (GCAA) adopted at COP22 that effectively amended and rebranded the LPAA (El Haite and Tubiana 2016; see also Kuyper et al. 2018). Its key features are:

- a more focussed mandate for the TEMs to be "focused on international collaboration and dialogue among Parties and non-Party Stakeholders" (El Haite and Tubiana 2016, p. 5);

- the establishment of regional thematic meetings with support of the UNFCCC's Regional Collaboration Centres in Bangkok (Thailand), Bogotá (Colombia), Kampala (Uganda), Lomé (Togo), and St. George (Grenada);

- and an annual engagement cycle that takes advantage of the full year and not only of the annual COP and formal intersessional meetings. 
All this clearly demonstrates that the recognition of transnational climate initiatives by the UNFCCC is not only a lip service, but various technical and political fora exist in which achievements of transnational climate initiatives have been highlighted. Still, from the observations of the LPAA in Paris, one gets the impression that this recognition is rather a means to amplify and publicise the initiatives to the media and the outside world than as an input for the negotiation process. In fact, the LPAA was still rather detached from the core negotiations in Paris, not only in terms of content but also physically: the LPAA meetings were held at the official side event space in a building separate from the negotiation rooms. At COP23, this was even more salient as negotiations were held in a separate "Bula Zone" some 1.5 kilometres away from the "Bonn Zone" in which the "climate change trade-fair" was held with all side-events, expositions and spaces for stakeholder engagement. While this may have been a logistical necessity, it still contributed to the divide between the intergovernmental negotiation process on the one hand and transnational engagement on the other.

All things considered, the few arenas open to input from non-state and subnational actors-reporting to the NAZCA platform, presenting in the TEP and highlighting initiatives in high-level events-had only a limited effect on negotiators and in particular the latter were directed mainly to an audience of observers and the press rather than party delegations. This clearly reflects what Widerberg and Pattberg have aptly described: "the 'international' and the 'transnational' have been largely separated both in academia and in practice" (Pattberg and Widerberg 2015, p. 694).

\subsection{Transnational initiatives and the national level}

As indicated in Fig. 2 above, interaction between the transnational realm and intergovernmental negotiations is not limited to the direct structuration channels discussed above, but also can occur indirectly but transnational initiatives can also feedback into the intergovernmental process through influencing national discourses and national governments, respectively. Note that this section does not address the influence of transnational governance initiatives on national climate policies in general but focuses on deliberations at the national level with respect to a given countries stance in the intergovernmental negotiations, inter alia the processes of developing and updating NDCs.

Probably, the most salient example for the non-state and subnational discursive power of non-state and subnational actors is the response of a myriad of US states, municipalities, and businesses to the announcement by President Trump to withdraw from the Paris Agreement. Their activity culminated at COP23 when Michael Bloomberg, UN Special Envoy for Cities and Climate Change, and Jerry Brown, Governor of California, presented "America's Pledge" on behalf of some 2300 states, cities and businesses from the United States of America who pledged their continued support to the Paris Agreement despite President Trump's announcement to withdraw the United States from the Agreement (America's Pledge 2017). Collectively, "America's Pledge" covers 55 per cent of the US population and 40 per cent of the US annual emissions (Climate Interactive 2017). While the engagement of non-state and subnational actors, many of which are also members of larger transnational networks such as the Under-2-Coalition or the C40 cities network, may not be sufficient to fully compensate for the dismantling and role back of federal level policies in the US, it is estimated that the withdrawal from the Paris Agreement will have a relatively mild effect on US emissions (Betsill 2017; Cornwall 2017; Palacková 2017; Urpelainen and Van de Graaf 2017; Watts 2017). 
This response is encouraging with respect to the future of US climate policy performance. As Michael Bloomberg put it: "Non-state actors are driving the bus" (quoted in Gupta and Sarkar 2017). But it is also challenging conventional perceptions: what does it tell about the United States' sovereignty in foreign policy when the President announces to withdraw from an international agreement and at the same subnational authorities representing more than half the country's population pledge their allegiance to the same agreement, anyway? But this challenge is not only a theoretical one, but has started to show first practical implications: only days after President Trump's announcement in the Rose Garden of the White House, China's President Xi Jinping met with Governor Brown of California and struck a bilateral deal to boost cooperation on green technology (Office of Governor of the State of California 2017). This was the first time ever that China had signed such an agreement with a subnational actor (see also Ott et al. 2017).

Beyond this kind of discursive influence, there may also be more direct and more formalised channels by which feedback from non-state and subnational actors can influence deliberations at the national level (see also Chan et al. 2018). Argentina was not only the first country to revise and substantially increase the ambition of its NDC after the Paris Agreement was adopted. In the process of revising its pledge, the federal Government organised an inclusive stakeholder engagement process and requested non-state and subnational actors to submit their own contributions (UNDP 2017). The process was organised by a cross-ministerial cabinet (Gabinete Nacional de Cambio Climático). In order to collect the input from various actors, a series of sectoral roundtables were held. The implementation of Argentina's NDC is now to be facilitated by a set of sectoral action plans which are again to be developed on the basis of input from non-state and subnational stakeholders (Ministerio de Ambiente y Desarrollo Sustenable de la República Argentina 2017; see also Chan et al. 2018).

While the result of the deliberations, the revised Argentinian NDC is still rated "highly insufficient" to effectively attain the goals of the Paris Agreement (Climate Action Tracker 2017), the inclusive process in which climate pledges from subnational and non-state actors were collated in order to inform and inspire the national ambition can serve as a blueprint for other countries as well (see Bäckstrand et al. 2017).

\section{Discussion: how to close the feedback loop?}

Both the theoretical model as well as well as the literature discussed in Sect. 2 suggest that "catalytic linkages" between the transnational realm of the global climate governance landscape and the intergovernmental negotiations could strengthen the global response to climate change. Yet, the empirical analysis demonstrates that currently, the ways in which transnational initiatives and the intergovernmental negotiation process interact is limited. Specifically, there is a significant imbalance in the sense that structuration may occur in one direct-from the UNFCCC and its negotiation process towards transnational initiatives - but feedback severely limited from the transnational realm into the intergovernmental negotiation process.

Numerous ways exist in which the UNFCCC Secretariat tries to coordinate and orchestrate transnational actors, and with some success. The UNFCCC formally recognises the complementary role of transnational governance initiatives. Decisions taken in Paris and thereafter further promote this by providing a continued mandate for the TEPs and institutionalising it under the joint auspices of SBI and SBSTA. The continuation of what 
started as the LPAA and has become the Global Climate Action Agenda is also a laudable development, as it provides an opportunity to communicate at an appropriate level new initiatives and/or increased level of ambition of existing coalitions. An important next step would be to establish these processes permanently, current mandates only cover the period until 2020.

Yet, the analysis also reveals, that "catalytic linkages" currently mostly run into one direction. While there is ample evidence that the efforts of coordinating and orchestrating the transnational realm are having some positive effect, there is actually very little that indicates that successful transnational governance resonates positively in the intergovernmental negotiations. Exemptions to this rule can be found where non-state and subnational actors have found ways to influence the national level directly, be it through discursive means as in the case of the United States or through more formal recognition and participation in deliberations at the national level like in Argentina.

Institutionalising mechanisms by which transnational governance initiatives can feed back into the intergovernmental negotiations could help address this shortfall. One way to do this would be to link the TEPs with provisions to be developed with respect to the matter of the global stocktake, the transparency framework, and possibly the facilitative compliance mechanism of the Paris Agreement Article 13 (UNFCCC 2016a, Art. 13-15). The Paris Agreement has established a 5-yearly cycle (starting in 2023) "to take stock of the implementation of this Agreement to assess the collective progress [...]. It shall do so in a comprehensive and facilitative manner" (UNFCCC 2016a, Art. 15). As current NDCs are widely out of line with the Paris Agreements long-term goal (UNFCCC 2016d), the first global stocktake will almost certainly identify a significant gap. Transnational climate initiatives not only can contribute to close this gap, insights and experiences from transnational climate initiatives, condensed and refined through the TEPs, may help to identify viable solutions that can then be taken up by nation states in their subsequent NDCs.

Linking the TEPs with the transparency framework of the Paris Agreement would create an even closer structuration channel. In Paris, Parties decided to launch a work programme on the transparency framework (UNFCCC 2016b, paras. 91-98). The purpose of the transparency framework is inter alia to track progress towards achieving individual NDCs (UNFCCC 2016a, Art. 13.5). The framework specifies information requirements and mandates a technical expert review. Explicitly, the "review shall also identify areas of improvement for the Party" (UNFCCC 2016a, Art. 13.12). One open question is, whether the expert review should focus on the national inventories parties are obliged to submit (Art. 13.7a) and to what extent the information on the implementation and attainment of NDCs (Art. 13.7b) is the subject of external review. Specifically the latter could be facilitated by and through the TEPs. Reviewers should make specific recommendations for each country drawing on the portfolio of good practices developed and maintained in the TEPs. What is more, non-state actors could not only provide input in terms of good practices but could also help to hold national governments accountable by providing critical perspectives on national reporting (see van Asselt 2016).

One step further even would be to link the TEPs to the compliance mechanism of the Paris Agreement. Article 15.2 establishes a compliance committee that is "facilitative in nature and function in a manner that is transparent, non-adversarial and non-punitive" (UNFCCC 2016a, Art. 15.2). Formulating recommendations or requirements based on the results of the TEPs could strike a balance between the non-punitive and non-adversarial nature of the compliance committee, yet maintain some form of compulsion. Arguably, this would affect to some extent national sovereignty and may therefore be difficult to agree on internationally. But formulating the recommendations in the form of a directive that leaves 
some leeway for the concerned Party with respect to the details of the implementation may reconcile these concerns.

Linking the outcomes of the TEPs more closely to the Paris Agreement's transparency and compliance mechanisms would affect the structure of the TEPs themselves. On the one hand, having a more specific objective such as establishing a "policy menu" from which technical experts and the compliance committee can draw, could help the UNFCCC Secretariat, the high-level champions as well as the respective COP Presidencies to structure the dialogues in a more focused way (see Höhne et al. 2014). On the other hand, it would certainly politicise the discussions. When the format of the technical expert meeting was put forward by AOSIS, the specific intention was to establish a "safe space" for facilitative dialogue (expert B). However, most observers agree that such a facilitative and nonpolitical dialogue never really developed in the originally intended way anyway (experts A and B, author's observation). Instead, the TEPs could become a hook to establish a more formal relationship between the intergovernmental regime and the wide range of transnational governance.

\section{Conclusions}

This article made three separate contributions to the academic debate on the role of nonstate and subnational actors in the global governance landscape and in particular with respect to the relationship of the intergovernmental and transnational realms of it: firstly, it provided an explicit conceptualisation of the relationship between the intergovernmental negotiations on the hand and transnational governance efforts. This theoretical contribution complements earlier advances made that focussed on the role of non-state actors as "NGO diplomats" (Betsill and Corell 2008) but did not recognise the increasingly important role of numerous non-state and subnational actors as governors in their own right.

Secondly, it provides an empirical analysis of the state of play of the interplay between the highly dynamic field of transnational governance initiatives and how they are being recognised and appreciated in the intergovernmental negotiations. The UNFCCC has started to recognise transnational climate initiatives and the work of non-party actors in recent years, but to date the institutional design still largely resembles a structurational one-way street: the UNFCCC provides legitimation to transnational climate initiatives, but there is no way for such initiatives to immediately feed back some of the positive dynamics they have created.

Yet, the structurational regime model suggests that more tightly knit feedback loops between the two spheres of governance could help improve the efficacy of global climate governance. As a third contribution, the article has proposed to establish more direct structuration channels in order to facilitate catalytic interactions by linking the (permanent) TEPs with key elements of the Paris Agreement: the global stocktake, the transparency framework and the compliance mechanism.

According to Keohane and Victor (2011), the climate change regime complex is organised non-hierarchically. The advent of the Paris Agreement now reconfigures this regime complex by introducing a new layer of hierarchy in and between the transnational and the international level to form of governance architecture that has been called "hybrid multilateralism" (Bäckstrand et al. 2017, p. 562; Kuyper et al. 2018). The Paris Agreement is not hierarchically superior to transnational governance initiatives in that it has effective control over those initiatives. Yet, the results in terms of mitigation outcomes of (successful) transnational governance inevitably materialise in the GHG inventories of nation states. These 
inventories, in turn, are pivotal in determining the adequacy of national climate governance and serve as critical input to subsequent climate policy goals in the cyclical NDC process deployed by the Paris Agreement. All transnational orchestration is vain if it does not resonate with the intergovernmental process. At a point where time is the most important constraining factor of climate governance, productive interactions between the transnational and international levels should be maximised on all levels in order to exploit the complementarities of the various governance approaches.

Acknowledgements The author would like to acknowledge helpful comments on earlier versions of the manuscript by Philipp Pattberg, Sander Chan, Florian Mersmann, Christiane Beuermann, and two anonymous reviewers. Special thanks go to the four interviewees. All remaining errors are my own.

Open Access This article is distributed under the terms of the Creative Commons Attribution 4.0 International License (http://creativecommons.org/licenses/by/4.0/), which permits unrestricted use, distribution, and reproduction in any medium, provided you give appropriate credit to the original author(s) and the source, provide a link to the Creative Commons license, and indicate if changes were made.

\section{References}

Abbott, K. W. (2012). The transnational regime complex for climate change. Environment and Planning C: Government and Policy, 30(4), 571-590. https://doi.org/10.1068/c11127.

Abbott, K. W., Genschel, P., Snidal, D., \& Zangl, B. (2015). International organizations as orchestrators. Cambridge: Cambridge University Press.

America's Pledge. (2017). America's pledge on climate change. Americas Pledge On Climate. https://www. americaspledgeonclimate.com/. Accessed January 19, 2018.

Andersen, S. O. (2015). Lessons from the stratospheric ozone layer protection for climate. Journal of Environmental Studies and Sciences, 5(2), 143-162. https://doi.org/10.1007/s13412-014-0213-9.

Andersen, S. O., \& Sarma, K. M. (2002). Protecting the ozone layer: The United Nations history. Sterling, VA: Earthscan Publications.

Arts, B. (2000). Regimes, non-state actors and the state system: A "structurational" regime model. European Journal of International Relations, 6(4), 513-542. https://doi.org/10.1177/135406610000600 4003.

Aykut, S. C., Foyer, J., \& Morena, E. (Eds.). (2017). Globalising the climate: COP21 and the climatisation of global debates (1st ed.). London: Routledge.

Bäckstrand, K., Kuyper, J. W., Linnér, B.-O., \& Lövbrand, E. (2017). Non-state actors in global climate governance: From Copenhagen to Paris and beyond. Environmental Politics, 26(4), 561-579. https:// doi.org/10.1080/09644016.2017.1327485.

Betsill, M. M. (2015). Building productive links between the UNFCCC and the broader global climate governance landscape 1. Global Environmental Politics, 15(2), 1-10. https://doi.org/10.1162/ GLEP_a_00294.

Betsill, M. M. (2017). Trump's Paris withdrawal and the reconfiguration of global climate change governance. Chinese Journal of Population Resources and Environment, 15(3), 189-191. https://doi. org/10.1080/10042857.2017.1343908.

Betsill, M. M., \& Corell, E. (2008). NGO diplomacy: The influence of nongovernmental organizations in international environmental negotiations. Cambridge, MA: MIT Press.

Biermann, F., Pattberg, P., van Asselt, H., \& Zelli, F. (2009). The fragmentation of global governance architectures: A framework for analysis. Global Environmental Politics, 9, 14-40. https://doi.org/10.1162/ glep.2009.9.4.14.

Bulkeley, H., Andonova, L., Betsill, M. M., Compagnon, D., Hale, T., Hoffmann, M. J., et al. (2014). Transnational climate change governance. Cambridge: Cambridge University Press.

Cao, X., \& Ward, H. (2017). Transnational climate governance networks and domestic regulatory action. International Interactions, 43(1), 76-102. https://doi.org/10.1080/03050629.2016.1220162.

Chan, S., Ellinger, P., \& Widerberg, O. (2018). Exploring national and regional orchestration of non-state action for a $<1.5{ }^{\circ} \mathrm{C}$ world. International Environmental Agreements: Politics, Law and Economics. https://doi.org/10.1007/s10784-018-9384-2. 
Chan, S., \& Pauw, P. (2014). A global framework for climate action-Orchestrating non-state and subnational initiatives for more effective global climate governance (Discussion Paper No. 34/2014). Bonn: Deutsches Institut für Entwicklungspolitik. http://www.die-gdi.de/uploads/media/DP_34.2014.pdf. Accessed April 7, 2018.

Climate Action Tracker. (2017). Assessment of the argentinian NDC. http://climateactiontracker.org/count ries/argentina.html. Accessed January 22, 2018.

Climate Interactive. (2017). US subnational climate action. Climate Interactive. https://www.climateinteract ive.org/programs/us-subnational-climate-action/. Accessed January 22, 2018.

Cornwall, W. (2017). Can U.S. states and cities overcome Paris exit? Science, 356(6342), 1000. https://doi. org/10.1126/science.356.6342.1000.

De Búrca, G., Keohane, R. O., \& Sabel, C. (2014). Global experimentalist governance. British Journal of Political Science, 44(3), 477-486. https://doi.org/10.1017/S0007123414000076.

El Haite, H., \& Tubiana, L. (2016). Marrakech partnership for global climate action. UNFCCC. https:// unfccc.int/files/paris_agreement/application/pdf/marrakech_partnership_for_global_climate_actio n.pdf. Accessed April 7, 2018.

Geels, F. W., \& Schot, J. (2010). The dynamics of transitions: A socio-technical perspective. In J. Grin, J. Rotmans, \& J. Schot (Eds.), Transitions to sustainable development-New directions in the study of long term transformative change (pp. 11-104). New York: Routledge.

Giddens, A. (1984). The constitution of society: Outline of the theory of structuration. Berkeley: University of California Press.

Gonzalez, M., Taddonio, K. N., \& Sherman, N. J. (2015). The Montreal Protocol: How today's successes offer a pathway to the future. Journal of Environmental Studies and Sciences, 5(2), 122-129. https:// doi.org/10.1007/s13412-014-0208-6.

Graichen, P., Healy, S., Siemons, A., Höhne, N., Kuramochi, T., Gonzales-Zuniga, S., et al. (2016). International climate initiatives-A way forward to close the emissions gap? Initiatives' potential and role under the Paris Agreement (Discussion Paper No. 31/2016). Dessau-Roßlau: Umweltbundesamt. http:// www.umweltbundesamt.de/publikationen/international-climate-initiatives-a-way-forward-to. Accessed January 10, 2017.

Grubb, M. (2010). Copenhagen: Back to the future. Climate Policy, 10(2), 127-130.

Gupta, J., \& Sarkar, S. (2017). "Non-state actors are driving the bus": The role of the US at COP23. https ://www.thethirdpole.net/2017/11/15/non-state-actors-are-driving-the-bus-the-role-of-the-us-at-cop23/. Accessed April 7, 2018.

Haas, P. M. (1992). Introduction: Epistemic communities and international policy coordination. International Organization, 46(01), 1-35. https://doi.org/10.1017/S0020818300001442.

Hale, T., \& Roger, C. (2014). Orchestration and transnational climate governance. The Review of International Organizations, 9(1), 59-82. https://doi.org/10.1007/s11558-013-9174-0.

Hermwille, L. (2016a). Climate change as a transformation challenge-A new climate policy paradigm? GAIA: Ecological Perspectives for Science and Society, 25(1), 19-22. https://doi.org/10.14512/ gaia.25.1.6.

Hermwille, L. (2016b). The role of narratives in socio-technical transitions-Fukushima and the energy regimes of Japan, Germany, and the United Kingdom. Energy Research \& Social Science, 11, 237246. https://doi.org/10.1016/j.erss.2015.11.001.

Hermwille, L., Obergassel, W., Ott, H. E., \& Beuermann, C. (2017). UNFCCC before and after ParisWhat's necessary for an effective climate regime? Climate Policy, 17(2), 150-170. https://doi. org/10.1080/14693062.2015.1115231.

Hoffmann, M. J. (2011). Climate governance at the crossroads: Experimenting with a global response after Kyoto. Oxford: Oxford University Press.

Höhne, N., Braun, N., Ellermann, C., \& Blok, K. (2014). Towards a policy menu to strengthen the ambition to mitigate greenhouse gases. Cologne: Ecofys. http://www.ecofys.com/files/files/ecofys-2014-towar ds-a-policy-menu-to-mitigate-ghg.pdf. Accessed April 7, 2018.

IISD Reporting Services. (2018). Earth negotiation bulletin-Coverage of climate and atmosphere meetings. http://enb.iisd.org/process/climate_atm.htm\#climate. Accessed January 19, 2018.

IPCC. (2014). Chapter 13-International cooperation: Agreements and instruments. In Climate change 2014: Mitigation of climate change. Contribution of working group III to the fifth assessment report of the intergovernmental panel on climate change (pp. 1001-1082). Cambridge: Cambridge University Press.

Jordan, A., \& Huitema, D. (2014). Policy innovation in a changing climate: Sources, patterns and effects. Global Environmental Change, 29, 387-394. https://doi.org/10.1016/j.gloenvcha.2014.09.005. 
Jordan, A., Huitema, D., Hildén, M., van Asselt, H., Rayner, T. J., Schoenefeld, J. J., et al. (2015). Emergence of polycentric climate governance and its future prospects. Nature Climate Change. https://doi. org/10.1038/nclimate2725.

Keohane, R. O., \& Victor, D. G. (2011). The regime complex for climate change. Perspectives on Politics, 9(01), 7-23. https://doi.org/10.1017/S1537592710004068.

Kuyper, J. W., Linnér, B.-O., \& Schroeder, H. (2018). Non-state actors in hybrid global climate governance: Justice, legitimacy, and effectiveness in a post-Paris era. Wiley Interdisciplinary Reviews: Climate Change. https://doi.org/10.1002/wcc.497.

McGinnis, M., \& Ostrom, E. (1996). Design principles for local and global commons. In O. R. Young (Ed.), The international political economy and international institutions (Vol. 2, pp. 465-493). Cheltenham: Edward Elgar Publishing.

Meadows, D. H. (1999). Leverage points-Places to intervene in a system. Hartland, VT: The Sustainability Institute. http://donellameadows.org/wp-content/userfiles/Leverage_Points.pdf. Accessed May 6, 2016.

Michaelowa, K., \& Michaelowa, A. (2017). Transnational climate governance initiatives: Designed for effective climate change mitigation? International Interactions, 43(1), 129-155.

Milkoreit, M. (2017). Mindmade politics: The cognitive roots of international climate governance. Cambridge, MA: MIT Press.

Ministerio de Ambiente y Desarrollo Sustenable de la República Argentina. (2017). Gabinete Nacional de Cambio Climático. Borrador Informe 2017. Buenos Aires: Dirección Nacional de Cambio Climático, Subsecretaría Cambio Climático y Desarrollo Sustenable.

Miskimmon, A., O’Loughlin, B., \& Roselle, L. (2013). Strategic narratives: Communication power and the new world order. New York: Routledge.

Morseletto, P., Biermann, F., \& Pattberg, P. (2016). Governing by targets: Reductio ad unum and evolution of the two-degree climate target. International Environmental Agreements: Politics, Law and Economics. https://doi.org/10.1007/s10784-016-9336-7.

Nasiritousi, N., Hjerpe, M., \& Linnér, B.-O. (2016). The roles of non-state actors in climate change governance: Understanding agency through governance profiles. International Environmental Agreements: Politics, Law and Economics, 16(1), 109-126. https://doi.org/10.1007/s10784-014-9243-8.

Newell, P. (2000). Climate for change: Non-state actors and the global politics of the greenhouse. Cambridge: Cambridge University Press.

Newell, P., Pattberg, P., \& Schroeder, H. (2012). Multiactor governance and the environment. Annual Review of Environment and Resources, 37(1), 365-387. https://doi.org/10.1146/annurev-envir on-020911-094659.

North, D. C. (1990). Institutions, institutional change and economic performance. Cambridge [etc.]: Cambridge University Press.

Obergassel, W., Arens, C., Hermwille, L., Kreibich, N., Mersmann, F., Ott, H. E., et al. (2015). Phoenix from the ashes: An analysis of the Paris Agreement to the United Nations Framework Convention on Climate Change-Part I. Environmental Law and Management, 27, 243-262.

Obergassel, W., Arens, C., Hermwille, L., Kreibich, N., Mersmann, F., Ott, H. E., et al. (2016). Phoenix from the ashes: An analysis of the Paris Agreement to the United Nations Framework Convention on Climate Change-Part II. Environmental Law and Management, 28, 3-12.

Oberthür, S. (2016). Reflections on global climate politics post Paris: Power, interests and polycentricity. The International Spectator, 51(4), 80-94. https://doi.org/10.1080/03932729.2016.1242256.

Oberthür, S., \& Gehring, T. (Eds.). (2006). Institutional interaction in global environmental governance: Synergy and conflict among international and EU policies. Cambridge, MA: MIT Press.

Office of Governor of the State of California. (2017). Governor Brown Meets with President Xi of the People's Republic of China, Signs Agreement with National Government to Boost Green Technology. http://gov.ca.gov/news.php?id=19832. Accessed January 22, 2018.

Okereke, C., Bulkeley, H., \& Schroeder, H. (2009). Conceptualizing climate governance beyond the international regime. Global Environmental Politics, 9(1), 58-78. https://doi.org/10.1162/glep.2009.9.1.58.

Ostrom, E. (2014). A polycentric approach for coping with climate change. Annals of Economics and Finance, 15(1), 97-134.

Ott, H. E., Hermwille, L., \& Obergassel, W. (2017). International climate policy: Trumping trump (inbrief No. 3-2017). Wuppertal/Berlin: Wuppertal Institute for Climate, Environment and Energy. https:// wupperinst.org/fa/redaktion/downloads/publications/In_Brief_2017-3_en.pdf. Accessed July 21, 2017.

Ott, H. E., Obergassel, W., Arens, C., Hermwille, L., Mersmann, F., \& Wang-Helmreich, H. (2014). Climate policy: Road works and new horizons-An assessment of the UNFCCC process from Lima to Paris and beyond. Environmental Liability, 22(6), 223-238. 
Overdevest, C., \& Zeitlin, J. (2014). Assembling an experimentalist regime: Transnational governance interactions in the forest sector. Regulation \& Governance, 8(1), 22-48. https://doi.org/10.111 1/j.1748-5991.2012.01133.x.

Palacková, E. (2017). The race for climate leadership in the era of Trump and multilevel governance. European View, 16(2), 251-260. https://doi.org/10.1007/s12290-017-0451-9.

Pattberg, P., \& Widerberg, O. (2015). Theorising global environmental governance: Key findings and future questions. Millennium-Journal of International Studies, 43(2), 684-705. https://doi.org/10.1177/03058 29814561773.

Pattberg, P., \& Widerberg, O. (2017). The climate change regime. In H. von Storch (ed.) Oxford research encyclopedia of climate science. Oxford: Oxford University Press. http://dx.doi.org/10.1093/acref ore/9780190228620.013.46. Accessed January 2, 2018.

Pattberg, P., Widerberg, O., Isailovic, M., \& Dias Guerra, F. (2014). Mapping and measuring fragmentation in global governance architectures: A framework for analysis (Working Paper No. R-14/34). Amsterdam: IVM Institute for Environmental Studies, VU Amsterdam. http://papers.ssrn.com/sol3/paper s.cfm?abstract_id=2484513. Accessed February 23, 2016.

Republique Française. (2015). The commitments of the Lima-Paris Action Agenda and the actions announced by Ségolène Royal. Paris: Ministère de L'Ecologie du Développement Durable et de L'Énergie de la République Française. http://www.developpement-durable.gouv.fr/IMG/pdf/201512-11_DP_Agenda_Solutions_Engl.pdf. Accessed February 19, 2017.

Roelfsema, M., Harmsen, M., Olivier, J. J. G., Hof, A. F., \& van Vuuren, D. P. (2018). Integrated assessment of international climate mitigation commitments outside the UNFCCC. Global Environmental Change, 48, 67-75. https://doi.org/10.1016/j.gloenvcha.2017.11.001.

Sabel, C. F., \& Zeitlin, J. (2008). Learning from difference: The new architecture of experimentalist governance in the EU. European Law Journal, 14(3), 271-327. https://doi.org/10.111 1/j.1468-0386.2008.00415.x.

Sabel, C. F., \& Zeitlin, J. (2012). Experimentalist governance. In D. Levi-Faur (Ed.), The Oxford handbook of governance (pp. 169-186). Oxford: Oxford University Press.

Schroeder, H., \& Lovell, H. (2012). The role of non-nation-state actors and side events in the international climate negotiations. Climate Policy, 12(1), 23-37. https://doi.org/10.1080/14693 062.2011 .579328 .

Sewell, W. H. J. (2005). Logics of history: Social theory and social transformation. Chicago: University of Chicago Press.

Smith, A. (2007). Translating sustainabilities between green niches and socio-technical regimes. Technology Analysis \& Strategic Management, 19(4), 427-450. https://doi.org/10.1080/09537320701403334.

Smith, A., \& Raven, R. (2012). What is protective space? Reconsidering niches in transitions to sustainability. Research Policy, 41(6), 1025-1036. https://doi.org/10.1016/j.respol.2011.12.012.

Sterk, W., Arens, C., Hermwille, L., Kreibich, N., Mersmann, F., \& Wehnert, T. (2013). Warsaw groundhog days. Wuppertal: Wuppertal Institute for Climate, Environment and Energy. http://wupperinst .org/a/wi/a/s/ad/2447/. Accessed April 7, 2018.

Stones, R. (2005). Structuration theory. Basingstoke: Palgrave Macmillan.

UNDP. (2017). Argentina goes subnational. NDC Support Programme. http://www.undp.org/content/ ndc-support-programme/en/home/presscenter/articles/2017/05/16/argentina-goes-subnational.html. Accessed November 22, 2017

UNFCCC. (2015). Decision 1/CP.20_Lima call for climate action (Document FCCC/CP/2014/10/ Add.1). Lima: UNFCCC.

UNFCCC. (2016a). Paris agreement. Bonn: United Nations Convention on Climate Change (UNFCCC). http://unfccc.int/files/meetings/paris_nov_2015/application/pdf/paris_agreement_english_.pdf. Accessed March 3, 2016

UNFCCC. (2016b). Report of the conference of the parties on its twenty-first session, held in Paris from 30 November to 13 December 2015 (No. FCCC/CP/2015/10/Add.1). Paris: United Nations Convention on Climate Change (UNFCCC). http://unfccc.int/resource/docs/2015/cop21/eng/10a01.pdf. Accessed February 3, 2016.

UNFCCC. (2016c). Climateaction2020.unfccc.int. http://climateaction2020.unfccc.int/. Accessed December 5, 2016.

UNFCCC. (2016d). Aggregate effect of the intended nationally determined contributions: An update (Document FCCC/CP/2016/2). Bonn: United Nations Framework Convention on Climate Change. http://unfccc.int/focus/indc_portal/items/9240.php. Accessed February 29, 2016.

UNFCCC. (2017). Assessment of the technical examination processes on mitigation and adaptation (Draft Decision No. FCCC/CP/2017/L.2). Bonn: UNFCCC. http://unfccc.int/resource/docs/2017/ cop23/eng/102.pdf. Accessed January 19, 2018. 
UNFCCC. (2018). NAZCA platform. http://climateaction.unfccc.int/. Accessed January 16, 2018.

United Nations. (1989). Montreal protocol on substances that deplete the ozone layer. https://treaties. un.org/doc/Publication/UNTS/Volume\%201522/volume-1522-I-26369-English.pdf. Accessed December 5, 2016.

Urpelainen, J., \& Van de Graaf, T. (2017). United States non-cooperation and the Paris agreement. Climate Policy. https://doi.org/10.1080/14693062.2017.1406843.

van Asselt, H. (2016). The role of non-state actors in reviewing ambition, implementation, and compliance under the Paris agreement. Climate Law, 6(1-2), 91-108.

Voß, J.-P., \& Simons, A. (2014). Instrument constituencies and the supply side of policy innovation: The social life of emissions trading. Environmental Politics, 23(5), 735-754. https://doi. org/10.1080/09644016.2014.923625.

Watts, M. (2017). Cities spearhead climate action. Nature Climate Change, 7(8), 537-538. https://doi. org/10.1038/nclimate3358.

Wendt, A. (1987). The agent-structure problem in international relations theory. International Organization, 41(03), 335-370. https://doi.org/10.1017/S002081830002751X.

Wettestad, J. (1999). Designing effective environmental regimes: The key conditions. Northampton, MA: Edward Elgar Publishing Ltd.

Widerberg, O., \& Pattberg, P. (2015). International cooperative initiatives in global climate governance: Raising the ambition level or delegitimizing the UNFCCC? Global Policy, 6(1), 45-56. https://doi. org/10.1111/1758-5899.12184.

Widerberg, O., \& Stripple, J. (2016). The expanding field of cooperative initiatives for decarbonization: A review of five databases: The expanding field of cooperative initiatives for decarbonization. Wiley Interdisciplinary Reviews: Climate Change. https://doi.org/10.1002/wcc.396.

Young, O. R. (Ed.). (1997). Global governance: Drawing insights from the environmental experience. Cambridge, MA: MIT Press.

Zelli, F. (2011). The fragmentation of the global climate governance architecture. Wiley Interdisciplinary Reviews: Climate Change, 2(2), 255-270. https://doi.org/10.1002/wcc.104. 